\title{
Academic Freedom in Europe: A Preliminary Comparative Analysis
}

\section{TERENCE KARRAN}

Centre for Educational Research and Development, University of Lincoln, LN6 7TS, U.K. Email:tkarran@Lincoln.ac.uk

[This is a post-peer-review, pre-copyedit version of an article published in Higher Education Policy. The definitive publisher-authenticated version 'Academic Freedom in Europe: A Preliminary Comparative Analysis', Higher Education Policy (2007) Vol. 20, No. 3, p.289313. is available online at: http://www.palgrave-journals.com/hep/journal/v20/n3/index.html]

ABSTRACT: Using comparative data from 23 states within the European Union, this paper is a preliminary assessment of the protection for, and (by extension) the health of, academic freedom in the universities of the nations of the European Union. The paper examines constitutional and legislative protection for academic freedom, along with legal regulations concerning institutional governance, the appointment of the Rector and the existence of academic tenure, in order to create a composite picture of the health of academic freedom in the universities within the European Union nations. Additionally the paper considers how this preliminary analysis could be extended through possible further research to aid refinement of the results, and what policy steps could usefully be adopted at European level to protect and strengthen academic freedom.

KEYWORDS: academic freedom; European Union; comparative analysis

\section{Introduction}

This paper's purpose is a comparative assessment of the protection for, and health of, academic freedom in the universities of the European Union. It is preliminary in that it addresses the constitutional and legislative frameworks in relation to academic freedom, thereby establishing the basis for subsequent empirical work to examine how the concept is interpreted and perceived by academic staff within their day to day work within Europe's Universities. The study's rationale is as follows. Firstly, academic freedom is considered important to the implementation of the Bologna Process. As the Salamanca Declaration of 2001 indicated, progress on the Bologna Process requires that 'European universities be empowered to act in line with the guiding principle of autonomy with accountability ... (and) ... confirm their adhesion to the principles of the Magna Charta Universitatum of 1988 and, in particular, academic freedom' (EUA, 2001, 1). Clearly, when academic freedom varies between nation states, the likelihood of mobility is reduced - staff and students are unlikely to desire to work or study in another university in which the academic freedom afforded to them 
is significantly lower than in their home institution. The Magna Charta Universitarum (EUA, 1988, 2) states: 'Freedom in research and training is the fundamental principle of university life, and governments and universities, each as far as in them lies, must ensure respect for this fundamental requirement' and, in a like vein, the Charter of Fundamental Rights of the European Union declaims in Article 13 that 'The arts and scientific research shall be free of constraint. Academic freedom shall be respected' (E.U., 2000, 11). However, neither of these documents provides any guidance as to what constitutes academic freedom, how it may be protected or nurtured, and whether therefore the presence (or absence) of academic freedom is supporting (or hindering) the implementation of the Bologna Process.

Secondly, despite the absence of a clear definition, it has nevertheless been asserted that academic freedom is under threat from the growth in the use of new information and communication technologies to deliver open and distance learning through cross national collaboration, which means that an academic could be located within a state in which academic freedom is protected yet providing a degree course in a country in which academic freedom is absent. Additionally, many such online courses are provided as a profitable service rather than a public good and, as Lieberwitz's study discovered, examination of these forprofit courses shows that 'they are not supportable on the grounds presented and that they undermine the basic principles of academic freedom and the independence of faculty ... (hence) ... arguments promoting the for-profit corporation require closer examination ... The assurances that academic freedom will be protected are illusory' (Lieberwitz, 2002, 115). Hence it is difficult to disagree with Altbach's prognosis that 'Academic freedom needs to be reconsidered in the era of the Internet' (Altbach, 2001, 208).

Thirdly, it has been asserted that academic freedom is threatened by the rising trend of managerialism in higher education. In his essay on The Interpretation of the Magna Charta Universitatum and its Principles, Lay $(2004,86)$ notes that 'the organisational structures of many universities have been gradually reformed away from a collegial and towards a more corporate model' and Rochford finds that 'The motivation for this shift has been a concern about the ability of the traditional collegiate structure to manage effectively' (Rochford, 2003, 252f). This shift has been endorsed by national governments, often acting on, and prompted by, the findings of national committees of inquiry. The Attali Report in France, the Bricall Report in Spain, and the Dearing Report in the U.K. all recommended a shift in governance in higher education towards less collegial and more corporate management structures. Assessing such trends, Standler $(2000,4)$, rightly comments that 'As in other areas of life, more management and control means less freedom. It is the same in the university. Surprisingly, 
scholarly articles on "academic freedom” rarely mention freedom from management as an important feature of academic freedom.' Among the dangers resulting from such trends, Tierney warns that 'If deans and departmental heads, for example, are seen exclusively as managers, a culture will be developed where academic freedom is irrelevant and may not even be discussed' (Tierney, 2001, 13).

The final rationale for the study is that there is a dearth of quantitative analyses of academic freedom, generally, and more especially within a European context. Hence Åkerlind and Kayrooz opine that 'To date, public debates and scholarly discussions about the nature of academic freedom have been marked by a lack of empirical data’ (Åkerlind and Kayrooz, 2002, 330). This view is endorsed by Rothblatt who comments that 'We do not as yet have a systematic historical analysis of the development of academic freedom conceptions and practices, especially one which allows us to compare periods, countries and systems' (Rothblatt, 1991, 21). Additionally, but more caustically, Standler states 'There is a large literature on academic freedom, mostly written by professors, and mostly consisting of selfserving praise and unsupported assertions' (Standler, 2000, 18). More helpful, perhaps, is Stuller's exhortation that 'Academic freedom is of unquestioned importance and it comes in many forms. ... In the spirit of inquiry then, courts and scholars alike should resolve that when they speak of academic freedom they will define their terms, ask the difficult questions and follow the argument where it leads' (Stuller, 1998, 342f).

\section{Measuring the Parameters of Academic Freedom}

In attempting to measure the parameters of academic freedom, there are three preliminary questions to be addressed. First, what parameters should be used? Answering this question is difficult as the principles and practice of academic freedom may vary between different nations. For example, in some nations universities and their staff may be anxious to protect the personal academic freedom of staff for teaching and research, but may be relatively unconcerned about the institutional freedom of the university in respect to its internal management and autonomy. In the absence of an agreed definition of academic freedom within the E.U., the 'Recommendations concerning the Status of Higher-Education Teaching Personnel' (UNESCO, 1997), produced by the International Association of Universities for UNESCO in 1997 were utilised, along with the substantial literature on academic freedom, to derive five different parameters which are considered to be important constituents of academic freedom. 
Secondly, how can the relative importance of these parameters be assessed? For example, does the inclusion of academic freedom within a nation's constitution provide better protection of academic freedom than inclusion within specific national legislation? Similarly, is academic tenure more important to the preservation of academic freedom than institutional self governance? Such qualitative questions can only really be addressed by asking the academic staff themselves, which is outside the purview of this analysis, although this study is able to provide some preliminary answers which would usefully guide such empirical research in the future. For this reason, in the absence of data as to the relative importance of various parameters of academic freedom, this study will assume that all such parameters are equally important.

Thirdly, how can these parameters be measured? Measurement is important in order to determine in which countries academic freedom is the strongest (in order to identify best practice) and weakest (in order to introduce measures so that an acceptable level of academic freedom is enjoyed in all universities in the E.U.). However, applying cardinal values to (for example) the constitutional protections for academic freedom may be impossible, although clearly some form of ordinal ranking may be feasible - for example, where one nation seeks to protect academic freedom by including it in the nation's constitution, while another does not. For this reason, it was decided to rank the parameters in generic terms of whether they afforded low, medium or high protection for academic freedom.

In order to assess the differing levels of legal protection for academic freedom within the European Union, data was gathered from 23 of the (then) 25 nations on both constitutional protections for, and specific legislation relating to, freedom of speech, academic freedom, institutional governance, the appointment of the Rector and academic tenure. Cyprus was excluded as part of it is controlled by Turkey, which is currently outside the E.U., and it proved impossible to get definitive information for the Belgian Communities. Gathering data on the constitutions of the nations was comparatively easy, as the importance of these documents is such that English translations freely exist. By contrast, English versions of less well known legislation on higher education are not readily available and, moreover, such laws are subject to periodic amendments as the systems of higher education in Europe evolve to meet new challenges. In addition, some states (for example, Poland and Portugal) have private universities, and although these are normally small in number, legislation may be passed specifically for them which may differ from the legislation enacted for publicly funded state universities. Consequently as Kwiek (2003), for example, reports, the situation in the private higher education institutions may be different from that in the publicly funded institutions. 
Moreover, in nations with federal constitutions, legislation protecting academic freedom within higher education may be passed at state, rather than federal level. Consequently, the information on individual member states provided in the tables represents a best estimate of current legislation as applied to public universities, rather than a definitive statement covering all higher education institutions.

Turning first to constitutional protection, data was gathered on the elements of the constitutions of the E.U. nations that relate to freedom of speech and academic freedom. This measure was used because the Constitution is the most important legal document within nation states and, moreover, there is an evident linkage between academic freedom and freedom of speech - as Connolly observes 'academic freedom is a kind of cousin of freedom of speech' (Connolly, 2000, 71). Consequently, Daughtrey $(1990,267)$ argues that 'The free speech guarantee serves as the basis of the concept of academic freedom,' an opinion shared by Turner $(1988,106)$ who believes that 'If academic freedom is not simple freedom of speech, it is an extension of the principle of free speech which is an essential prerequisite for the proper performance of the profession.'

All the 23 nation states, except the United Kingdom (which does not have a written constitution), have some protection for freedom of speech enshrined in their constitutional documents, although the Netherlands Constitution does not explicitly mention freedom of expression, but instead states that prior permission is not required before publication. By contrast, the law in the U.K. places legal restrictions on the freedom of expression, and anything not covered by these restrictions is deemed lawful. Although all states, bar one, have some form of constitutional protection for freedom of expression, eight have some caveats relating to the exercise of that freedom. The constitutions in four states indicate that freedom of speech is guaranteed, subject only to the repression of offences committed in the exercise of these freedoms. The remaining four states place limitations on freedom of speech on the general grounds of obscenity and indecency, the protection of children and young people, blasphemy, sedition, public order, incitement, insurrection, etc., while three mention specific restrictions in relation to an insult against the President, the right to personal honour and the disclosure of the capability of the armed forces. It would, therefore, be possible to conceive of situations when academic freedom could be circumscribed by these restrictions on freedom of speech, although such instances are likely to be small in number.

Although Smith's research revealed that 'Explicit protection of this (academic) freedom in a Bill of Rights is unusual' (Smith, 1995, 678), in thirteen E.U. nations academic freedom (freedom of scientific research and the arts and of teaching) is considered sufficiently 
important to be included in the constitution, although in Germany and Greece this freedom has limits, in that academic freedom and the freedom to teach do not override allegiance to (or the duty to obey) the Constitution. Furthermore, the constitution in eight countries guarantees the autonomy or self governance of higher education institutions, although in all but two states, this autonomy is exercised within the limits prescribed by specific higher education laws. In Estonia, Finland, Italy, Lithuania, Portugal, and Slovenia the Constitution guarantees both the freedom of teaching and research and also the autonomy of universities.

Clearly in those nations where the constitution mentions both freedom of speech and academic freedom (and explicitly details the freedom for teaching and research and institutional autonomy), protection for the principle of academic freedom is likely to be stronger than in those states where limitations are imposed or where only freedom of speech is mentioned, and in which protection for academic freedom may lie by reference to the interpretation of constitutional freedom of speech protection, a situation which occurs, for example, in the USA. Furthermore, in states where the constitution mentions neither academic freedom nor freedom of speech, the degree of constitutional protection for the principle of academic freedom is correspondingly low (if not non existent). On this basis, the degree of protection for academic freedom within the constitution was allocated the values of high, medium or low. Space does not permit inclusion of the full set of results (copies of which can be obtained on request from the author), however Table 1 contains illustrative examples demonstrating the approach taken.

The full set of results, from which the entries in table 1 are drawn, was used to create table 2, which indicates that a high level of protection for academic freedom exists in thirteen nations, a low level in two, with the remainder enjoying medium levels of protection.

Table 1 Constitutional protection for freedom of speech and academic freedom - examples

\begin{tabular}{|l|l|}
\hline $\begin{array}{c}\text { State/Level of } \\
\text { Protection }\end{array}$ & \multicolumn{1}{c|}{ Constitutional Statement on Academic Freedom and Freedom of Expressions } \\
\hline $\begin{array}{l}\text { Luxembourg } \\
\text { Medium }\end{array}$ & $\begin{array}{l}\text { Constitution adopted 17 Oct 1868 } \\
\text { Article 24 [Expression]: Freedom of speech in all matters and freedom of the press is } \\
\text { guaranteed, subject to the repression of offences committed in the exercise of these freedoms. } \\
\text { Table 2 Constitutional protection for freedom of speech and academic freedom - summary }\end{array}$ \\
\hline $\begin{array}{l}\text { Netherlands } \\
\text { Low }\end{array}$ & $\begin{array}{l}\text { The Netherlands Constitution } 2002 \\
\text { Article 71. No one shall require prior permission to publish thoughts or opinions through the } \\
\text { press, without prejudice to the responsibility of every person under the law. }\end{array}$ \\
\hline Spain & $\begin{array}{l}\text { Constitution of 29 Dec 1978 Article 20 [Specific Freedoms, Restrictions] } \\
\text { The following rights are recognized and protected: a) To express and disseminate thoughts } \\
\text { freely through words, writing, or any other means of reproduction; b) Literary, artistic, } \\
\text { scientific, and technical production, and creation; c) Academic freedom. } \\
\text { Article 27 [Education](10) The autonomy of universities is recognized under the terms } \\
\text { established by law }\end{array}$ \\
\hline
\end{tabular}


Table 2 Constitutional protection for freedom of speech and academic freedom - summary

\begin{tabular}{|c|c|c|c|}
\hline Nation & Level of Protection & Nation & Level of Protection \\
\hline Austria & High & Lithuania & High \\
\hline Czech Republic & High & Luxembourg & Medium \\
\hline Denmark & Medium & Malta & Medium \\
\hline Estonia & High & Netherlands & Low \\
\hline Finland & High & Poland & High \\
\hline France & Medium & Portugal & High \\
\hline Germany & Medium & Slovakia & High \\
\hline Greece & Medium & Slovenia & High \\
\hline Hungary & High & Spain & Medium \\
\hline Ireland & Medium & Sweden & N/A \\
\hline Italy & High & U.K. & \\
\hline Latvia & High & & \\
\hline
\end{tabular}

This initial analysis revealed that nearly half the E.U. states do not have protection for academic freedom and university autonomy written into their constitution. However, although protection for academic freedom may not be available under constitutional law, it may still be protected in other national legislation. Hence information on the national legislative instruments which relate to academic freedom and the protection of university autonomy was gathered. This demonstrated that, with the exception of Greece and Malta, all E.U. nations have some specific legislation relating to higher education which refers to academic freedom and/or university autonomy. However, the coverage and the detail vary considerably. For example, legislation in the Czech Republic, Ireland, Latvia, Poland, Slovakia, Slovenia, and Spain is more explicit than in other states, and specifies protection for academic freedom for teaching and research, and institutional autonomy. Legislation in Austria, France, Germany, Hungary, Italy, and Luxembourg, specifies freedom of teaching and research, but does not mention institutional autonomy. Of the remainder, some such as Lithuania mention academic freedom or autonomy, which, as in the case of Lithuania, is established by law and the statutes of the universities, while some nations just have a brief general statement - as in the case of the Netherlands where the law states that 'Academic freedom shall be respected within the institutions.' Interestingly, in Austria, not only does the legislation protect academic freedom, it also provides that individual academics cannot be forced to participate in academic work which conflicts with his/her conscience.

Applying comparative values to the protection offered by national legislation is difficult. However, logic dictates that academic freedom is likely to be better protected where reference to it is most explicit in law. Hence in nations like Greece where there is no legislation, and the Netherlands and Italy (in which short generalised statements are made), the protection of academic freedom by legislation will be lower than in countries like France, Latvia, and Slovenia, where detailed legislation ensures that the level of protection of academic freedom 
is high. For those nations occupying the middle ground between these extremes, a description of medium protection is most appropriate. On this basis, the degree of protection for academic freedom afforded by specific national legislation was allocated the values of high, medium or low. Table 3 below provides examples of some of the legislative instruments, and the scores ascribed to them.

Table 3 Specific legislation on academic freedom - examples

\begin{tabular}{|c|c|}
\hline $\begin{array}{l}\text { State/Level of } \\
\text { Protection }\end{array}$ & Specific legislation on academic freedom \\
\hline $\begin{array}{l}\text { Czech Republic } \\
\text { High }\end{array}$ & $\begin{array}{l}\text { Act on Higher Education Institutions No. 121/2004 : Article } 4 \text { The following academic } \\
\text { liberties and rights are guaranteed at higher education institutions: a) Freedom of science, } \\
\text { research and artistic activities as well as making the results public; b) Freedom of instruction, } \\
\text { namely its openness to variety of scholastic theories, scientific and research methods and } \\
\text { artistic trends; c) The right of learning that includes free choice of study specialisation within } \\
\text { the framework of study programmes as well as freedom of expressing one's opinion during } \\
\text { lecturing; d) The right of academic community members to elect their representative } \\
\text { academic bodies; }\end{array}$ \\
\hline $\begin{array}{l}\text { Poland } \\
\text { Medium }\end{array}$ & $\begin{array}{l}\text { Higher Education Law 2005: Article 4: } 1 \text {. Institutions of higher education shall be } \\
\text { autonomous in all areas of their operation, subject to provisions herein. } 2 \text {. In their operations, } \\
\text { institutions of higher education shall be guided by principles of freedom of teaching, freedom } \\
\text { of scientific research and freedom of artistic creation. }\end{array}$ \\
\hline $\begin{array}{l}\text { U.K. } \\
\text { Low }\end{array}$ & $\begin{array}{l}\text { Education Reform Act } 1988 \text { Part II - Higher and Further Education Section } 202 \text { (1) There } \\
\text { shall be a body of Commissioners known as the University Commissioners who shall } \\
\text { exercise, in accordance with subsection (2) below, in relation to qualifying institutions, the } \\
\text { functions assigned to them by those sections. (2) In exercising those functions, the } \\
\text { Commissioners shall have regard to the need (a) to ensure that academic staff have freedom } \\
\text { within the law to question and test received wisdom, and to put forward new ideas and } \\
\text { controversial or unpopular opinions, without placing themselves in jeopardy of losing their } \\
\text { jobs or privileges they may have at their institutions; (b) to enable qualifying institutions to } \\
\text { provide education, promote learning and engage in research efficiently and economically; and } \\
\text { (c) to apply the principles of justice and fairness. }\end{array}$ \\
\hline
\end{tabular}

It must be recognised that such a limited analysis is a discriminatory rather than objective exercise, providing at best probabilistic descriptions. However, such caveats notwithstanding, applying this process to all nation states produces the results shown in Table 4 below, which demonstrates that national legislation offers a high level of protection for academic freedom in eleven states, a low level in six, with the remainder enjoying medium levels of protection.

Table 4 Specific legislation protecting academic freedom - summary

\begin{tabular}{|c|c|c|c|}
\hline Nation & Level of Protection & Nation & Level of Protection \\
\hline Austria & Medium & Lithuania & High \\
\hline Czech Republic & High & Luxembourg & Medium \\
\hline Denmark & Medium & Malta & Low \\
\hline Estonia & Medium & Netherlands & Low \\
\hline Finland & High & Poland & Medium \\
\hline France & High & Portugal & Medium \\
\hline Germany & High & Slovakia & High \\
\hline Greece & N/A & Slovenia & High \\
\hline Hungary & High & Spain & Low \\
\hline Ireland & High & U.K. & Low \\
\hline Italy & Low & & \\
\hline Latvia & High & & \\
\hline
\end{tabular}


The situation in the U.K. constitutes a special case. Ostensibly the legislation enacted in 1988 provides protection for academic freedom, but its intention was to weaken rather than strengthen academic freedom, by removing tenure from academic staff. The bill applied only to academic staff appointed after November 20, 1987. Those appointed before that date were exempt from the Act, which was not extended to short-term contract research scientists or to most academic related staff. Similarly, the old polytechnics which were granted university status in 1992 were exempt, as their academic staff did not have tenure. That the primary intention of the legislation was not the protection of academic freedom was made clear when the Bill was introduced by the Minister, Kenneth Baker, who stated in Parliament that: 'In the case of universities, the Government's policy is that newly appointed staff should no longer be given "tenure", that is, special protection against dismissal on grounds of redundancy or financial exigency. The Bill provides (Clause 132) that staff currently in post who have tenure should retain it as long as they continue in their present appointments, but that those newly appointed or promoted to permanent posts after 20 November 1987 should no longer have this special protection' (HC Deb, 1987, cc771-81). Hence it is difficult to disagree with Court's opinion that 'Although the 1988 Act made specific reference to the protection of academic freedom, there must be doubt that staff engaged now in teaching and research at U.K. universities have the same liberty that existed in earlier times' (Court, 1998, 774).

Examination of the data in tables 2 and 4 reveals that the overwhelming majority of E.U. nations have both constitutional protection of freedom of speech and/academic freedom, allied to protection under specific legislation for universities. The aberrant case is the U.K. where there is no constitutional support for either freedom of speech or academic freedom, and the specific legislation was designed not to protect academic freedom, but as a supplementary clause guaranteeing “just cause” for the termination of academic employment, in a bill created to abolish tenure. This situation has lead Pritchard to argue that 'In the United Kingdom, the absence of a written Constitution ... has weakened British universities' attempts to defend themselves' (Pritchard, 1998, 121). This exception aside, the general constitutional and legislative prominence accorded to academic freedom suggests that the majority of E.U. nations regard the principle to be of cardinal importance, not only to universities but more generally to everyday life and the working of the state. Additionally, the nations formerly under the influence of the USSR, and which have joined the E.U. most recently, as a group seem to ascribe more importance to academic freedom. This confirms Thorens' observation that 'In the last few years - and this shows the pertinence of this issue - many countries emerging from authoritarian regimes have foreseen academic freedom in 
their laws on higher education and more especially in those that concern universities' (Thorens, 2006, 91).

The third parameter of academic freedom chosen for analysis is institutional autonomy and the internal governance of the university. In justification of the inclusion of this parameter, the UNESCO recommendations state that 'The proper enjoyment of academic freedom ... require(s) the autonomy of institutions of higher education. Autonomy is that degree of self-governance necessary for effective decision making by institutions of higher education regarding their academic work, standards, management and related activities ... and respect for academic freedom and human rights. Autonomy is the institutional form of academic freedom ... Higher education teaching personnel should have the right and opportunity, ... to take part in the governing bodies and ... they should also have the right to elect a majority of representatives to academic bodies within the higher education institution' (UNESCO, 1997, 28). These recommendations, although worthy, lack clarity. As Bricall points out, 'University autonomy needs to be distinguished from concepts it is often confused with, such as university self-management, collegial governance or academic freedom. ... An academic entity can be autonomous even if its internal decision making is not based on selfmanagement procedures' (Bricall, 2003, 59). Similarly, Berdahl makes the distinction between procedural autonomy, which is the power of the university to determine 'the means by which its goals and programmes will be pursued--the how of academe' and substantive autonomy, which is the power of the university to determine 'its own goals and programmes-if you will, the what of academe' (Berdahl, 1990, 174). In recent years governments in some E.U. states have given universities greater autonomy at institutional level, however as Lay (2004, 87) points out 'The collegial nature of traditional university organisation seems increasingly halcyon when contrasted with the harsh present-day reality of university staff being viewed as little more than production line workers on the knowledge-factory floor. ... That they have been excluded from the decisions that control the development of the modern university makes the concept of institutional autonomy appear increasingly hollow.' Moreover, as Rothblatt $(1999,17)$ emphasises 'institutional autonomy is not a guarantee of academic freedom. The institution itself, ... can inhibit or surpass academic freedom,' an opinion finding empirical endorsement in Anderson and Johnson's study of university autonomy in 20 countries which concluded that 'Institutional autonomy is a necessary but not a sufficient condition for academic freedom’ (Anderson and Johnson, 1998, 8).

On the basis of these arguments, the decision was taken to focus on self governance rather than institutional autonomy. This methodological decision has strong support from 
experts and institutions alike within the existing literature. For example the Association of American University Professors argues that 'sound governance practise and the exercise of academic freedom are closely connected, if not inextricably linked' (AAUP, 1994, 3), and that 'the faculty's role in governance, is the foundation of academic freedom' (Scott, 1994, 119). Similarly, Rochford has noted that 'A traditional institutional protection for academic freedoms is through the tradition of participation by faculty members in academic governance' (Rochford, 2003, 252). More pertinently, perhaps, commentators have noted the rise in managerialism, accompanied by a decline in democratic participation by faculty, and linked this to a weakening of academic freedom. As McMaster points out: 'Universities have always been managed: the guilds of scholars that made up the first universities were themselves hierarchies of authority. The main difference is that authority in current operational models of universities is seen to be related to managerial position and not to expertise within a discipline' (McMaster, 2002, 3). More bluntly, Nyborg describes the 'situation in which the permanent academic staff no longer holds the majority of votes on the governing body' as 'a significant departure from traditional European practice with considerable implications for higher education governance' (Nyborg, 2003, 3). Such trends lead Gerber to state that ‘in the context of today's misguided efforts to apply what is already a discredited corporate model of management to higher education, shared governance is taking on new importance as a means of trying to preserve the ideals of liberal education that are necessary for the continued vitality of our democratic society’ (Gerber, 2002, 23).

For this part of the study, data was gathered on legislation relating to University governance. In attempting to measure self-governance, where the supreme decision making body has a majority of faculty members, then the level of protection for the personal academic freedom of staff is likely to be high; conversely where this body excludes academic staff or has a majority of external members, then the level of protection will be low. Between these two positions will be a variety of governance models in which both the academic staff and external representatives have a significant voice but, owing to the presence of other represented groups (administrative staff, students, etc.), neither has a monopoly of decision making power. In such situations the level of protection for academic freedom will depend on the ability of faculty to persuade other actors, within the process of governance, of the importance of academic freedom. Despite such problems, it was possible to allocate the descriptors (high, medium, low) to the systems of governance, and table 5 below gives some examples as to how this was done. 
Table 5 Legislation on university governance - examples

\begin{tabular}{|c|c|}
\hline $\begin{array}{l}\text { State/Level of } \\
\text { Protection }\end{array}$ & Legislation on university governance \\
\hline $\begin{array}{l}\text { Lithuania } \\
\text { High }\end{array}$ & $\begin{array}{l}\text { Law On Higher Education } 21 \text { March } 2000 \text { No.Viii-1586. Article } 21 \text {. Higher Education } \\
\text { Establishment Self-government Bodies and Higher Education Establishment Public Regulation } \\
\text { Bodies : } 1 \text {. The supreme body of the academic self-government of a State university shall be } \\
\text { the senate } \\
\text { Article } 22 \text {. The Senate: } \\
\text { 1. The senate shall be formed in accordance with the procedure established by the university } \\
\text { statute for a period not longer than five years. } \\
\text { 2. University scientists, distinguished artists, students as well as scientists and distinguished } \\
\text { artists of other higher education establishments may be senate members. Students must } \\
\text { comprise not less than } 10 \text { percent of the Senate members. Representatives of students to the } \\
\text { Senate shall be delegated by the students' government organisation and if there is no } \\
\text { students' government organisation, representatives shall be elected by a general students' } \\
\text { meeting (conference). Professors must comprise not less than half of the senate members. } \\
\text { The university rector shall be an ex officio member of the Senate }\end{array}$ \\
\hline $\begin{array}{l}\text { Malta } \\
\text { Medium }\end{array}$ & $\begin{array}{l}\text { Education Act } 1991 \\
\text { Section .30. (1) The following shall be the governing bodies of the University:(a) the } \\
\text { Council;(b) the Senate;(c) the Faculty Boards. } \\
\text { Sect. 31. (1) The University shall have the power to make statutes, regulations, and bye-laws in } \\
\text { order to provide for i ts own administration and for the administration of its activities and of } \\
\text { the entities created by it. } \\
\text { Sect. } 32 \text { The Council of the University shall be composed as follows:(a) the Pro-Chancellor } \\
\text { who shall be ex officio president; (b) the Rector who shall be ex officio vice-president; (c) four } \\
\text { members representing the Senate; (d) two members elected by the academic staff from those } \\
\text { amongst them who are not members of the Senate; (e) two members elected by and from } \\
\text { among the non-academic staff; (f) two members elected by and from among the University } \\
\text { students; (g) one member appointed by the Minister and a member appointed by the Chairman } \\
\text { of the Foundation for Theological Studies; (h) a number of members appointed by the Prime } \\
\text { Minister from among the leading representatives of the economic, industrial and social fields, } \\
\text { to represent the general interest of the country, such number never to exceed the number of all } \\
\text { the members mentioned in paragraphs (c), (d), (e), (f) and (g). } \\
\text { Sect. 33. The Council shall be the supreme governing body of the University }\end{array}$ \\
\hline $\begin{array}{l}\text { Sweden } \\
\text { Low }\end{array}$ & $\begin{array}{l}\text { Higher Education Act Law } 1992 \text { Chapter } 2 \text {, S. } 2 \text { The governing body of an institution of higher } \\
\text { education shall supervise all matters concerning the institution of higher education and shall be } \\
\text { responsible for the performance of its duties. } \\
\text { S. } 4 \text { The government shall appoint the chairman of the governing body of an institution of } \\
\text { higher education.. The government shall appoint the majority of the other members of the } \\
\text { governing body. Teachers and students at the institution of higher education shall be entitled to } \\
\text { representation on the governing body. } \\
\text { Chapter } 2 \text {. Governing Bodies and Vice-Chancellors Composition of the Governing Body } \\
\text { Sect. } 1 \text { The governing body of an institution of higher education shall consist of the } \\
\text { chairman, vice-chancellor and not more than thirteen other members. The governing body } \\
\text { shall elect one of its members vice-chairman. Ordinance } 1998: 1003 \text {. Appointment of } \\
\text { Members of the Governing Body Sect. } 7 \text { Members other than the vice-chancellor shall be } \\
\text { appointed for a fixed period not exceeding three years. The teachers shall be entitled to } \\
\text { representation by three members on the governing body. The teacher representatives shall be } \\
\text { elected by ballot within the institution of higher education. The governing body shall issue } \\
\text { more precise regulations relating to election procedures. The students shall be entitled to } \\
\text { representation on the governing body by three members. }\end{array}$ \\
\hline
\end{tabular}

The data demonstrated that the systems of university governance (and the participatory role of academic staff) vary considerable within the EU. For example, in countries such as Poland, the Senate is the supreme decision making body of the university, and Professors, or staff holding a doctoral degree, must comprise more than half the Senate members. By 
contrast, in the Netherlands the Executive Board is charged with governing the university in its entirety and is appointed by the Supervisory Board, the members of which are all appointed and dismissed by the Minister. In some states the system of governance is complicated - many have a bi- or tri cameral system, involving, for example as in Portugal, the Senate, the University Assembly and the Administrative Council or as in Spain, the Social Council, the Council of Government and the University Senate. In other states the regulations specify minimum and maximum figures for participation. For example, in Ireland, the governing authority includes the chief officer, a person appointed as the chairperson, at least one but not more than two senior officers with responsibilities to the chief officer for academic, financial or administrative affairs, between 2 and 6 Professorial elected representatives, between 3 and 5 elected representatives from the other academic staff, between 1 and 3 representatives elected by the non-academic staff, between 2 and 3 elected officers from the Students Union and one representative elected by the post-graduate students. Clearly, where the academic staff enjoy their maximum allocation of representatives on the governing body, they will be in a more powerful position than if they are given their minimum allocation. Table 6 below summarises the findings and shows that, in thirteen states, the system of governance offers high protection for academic freedom, in five states the level of possible protection is low, with five states in the intermediary category.

Table 6 Legislation on university governance - summary

\begin{tabular}{|c|c|c|c|}
\hline Nation & Level of Protection & Nation & Level of Protection \\
\hline Austria & High & Lithuania & High \\
\hline Czech Republic & High & Luxembourg & Medium \\
\hline Denmark & Low & Malta & Medium \\
\hline Estonia & High & Netherlands & Low \\
\hline Finland & High & Poland & High \\
\hline France & Medium & Portugal & Medium \\
\hline Germany & High & Slovakia & High \\
\hline Greece & Medium & Slovenia & High \\
\hline Hungary & High & Spain & High \\
\hline Ireland & Low & Sweden & Low \\
\hline Italy & High & U.K. & \\
\hline Latvia & High & & \\
\hline
\end{tabular}

The fourth measure chosen for inclusion in the study is the method of appointment of the University Rector. This is not mentioned explicitly in the UNESCO recommendations, which nevertheless state that 'Autonomy should not be used by higher education institutions as a pretext to limit the rights of higher-education teaching personnel' and that 'Higher-education teaching personnel should have the right and opportunity, without discrimination of any kind, ... to criticize the functioning of higher education institutions, including their own' (UNESCO, 1997, 30). However as Standler notes 'A significant part of individual academic 
freedom is not a legal concept, but dependent on the internal culture among faculty and management (e.g. Department Chairmen, Deans, the Chancellor, and their administrative staff) at a university' (Standler, 2000, 3). In the past the Rectors were internal appointments, and saw part of their job as protecting the academic freedom of faculty. Thus Dodds (an exuniversity president) opines 'I know no college or university president for whom academic freedom is not a recurring source of concern. As chief executive of his institution he bears the brunt of criticisms and attacks by individuals and organizations, often inflamed by superpatriotism or anti-intellectual prejudices and fixations. ... In line of duty a president repeatedly defends the right of the faculty to express opinions and take action in areas over which he exercises no controls' (Dodds, 1963, 602).

However, the appointment process of Rectors in many E.U. nations is changing, leading Nyborg to note a trend away from the traditional model of institutional governance in which 'the academic community elects its own officers (rector, deans, university and faculty senates) with little or no outside interference' to institutions hiring 'leaders from outside the academic community, to replace the elected rector still found at the vast majority of higher education institutions' (Nyborg, 2003, 3). White’s examination of case studies showed that 'Presidents, trustees, and other powerful people who were opposed to the expression of unorthodox views and willing to use their power to suppress such expression could repeatedly threaten academic freedom' (White, 2000, 61). Similarly Tierney (2001, 4) details cases in Australia where (inter alia) an emeritus professor who criticised a proposed policy received a letter from the Vice Chancellor telling him to vacate his office (and position) for being discourteous. While Raelin reports that in 1991, after three philosophy lecturers at Swansea University in the U.K. criticized the academic standards of a new degree program, two were suspended from teaching and one resigned, leading the (then) Vice Chancellor to comment that in the business world 'those people ... would have been up the road the moment they kicked up the fuss' (Raelin, 2003, 42).

Clearly, where the Rector is chosen from the Faculty, by the Faculty, for a limited period in office, s/he is unlikely to take decisions which undermine the academic freedom of the staff, as s/he knows that at the end her/his term of office, someone else could be elected as Rector and take retaliatory actions against her/him. In such situations the level of protection for academic freedom will be high. By contrast, where the Rector is chosen from outside the university, and appointed for an indefinite term by an external agency, s/he will be in a position to abuse academic freedom, more especially where the faculty staff do not have the protection of tenure. In such situations the level of protection of academic freedom is low. In 
between these extremes will be different appointment procedures in which the academic staff can have a significant but not a determinant effect on the outcome. For example, the staff may be required to elect the Rector but from a shortlist drawn up externally, and without a right of veto or the ability to field their own preferred candidate. In such circumstances, the protection for academic freedom is likely to be only moderate. Table 7 gives some examples of how the descriptions of high, medium or low, were allocated in accordance with the analysis above.

Table 7 Legislation on the appointment of the rector - examples

\begin{tabular}{|l|l|}
\hline \multicolumn{1}{|c|}{$\begin{array}{c}\text { State/Level of } \\
\text { Protection }\end{array}$} & \multicolumn{1}{c|}{ Legislation on the appointment of the rector } \\
\hline Lenmark & $\begin{array}{l}\text { Act on Universities May } 282003 \\
10 .(7) \text { The Board shall employ and dismiss the Rector. } \\
12 \text { (2): The Board shall be composed of external members and members representing the } \\
\text { academic staff of the university, which includes PhD students with university contracts, the } \\
\text { technical and administrative staff and the students. The Board shall comprise a majority of } \\
\text { external members. The Board shall elect a chair from among its external members. } \\
14 . \text { (2) The Rector shall be an acknowledged researcher within one of the university's } \\
\text { academic fields and have knowledge of the educational sector. [The appointment is } \\
\text { advertised externally, the length of appointment varies, but five years plus an extension of an } \\
\text { additional three is usual] }\end{array}$ \\
\hline $\begin{array}{l}\text { Estonia } \\
\text { Medium }\end{array}$ & $\begin{array}{l}\text { Universities Act (Passed 12 January 1995, consolidated text May 2004) } \\
\text { Section 17 Rector (1) A Rector shall be elected for five years pursuant to the procedure } \\
\text { prescribed by the statutes of the university } \\
\text { Any person who is an Estonian citizen, who is or has been elected to the position of a } \\
\text { professor and who is less than 60 years of age may be a candidate for the position of Rector }\end{array}$ \\
\hline $\begin{array}{l}\text { Finland } \\
\text { High }\end{array}$ & $\begin{array}{l}\text { Universities Act (645/1997) Section 13 Rector and vice-rectors : (2) The rector shall be } \\
\text { elected for a five year term at a time. The rector shall be elected by a university electoral } \\
\text { college. } \\
\text { (The appointment is internal and renewable) }\end{array}$ \\
\hline
\end{tabular}

Applying these descriptions to the legislation relating to the appointment of the Rector in all countries, gives the results shown in table 8 below. As can be seen, in sixteen nations the appointment of Rector is still internal and with the academic staff exercising the major voice, in five states the system allows the academic staff a limited input into the choice of Rector, while in two nations the Rector's post is open to external candidates and the academic staff do not have a definitive impact on the choice.

Table 8 Legislation on the appointment of the rector - examples

\begin{tabular}{|c|c|c|c|}
\hline Nation & Level of Protection & Nation & Level of Protection \\
\hline Austria & High & Lithuania & High \\
\hline Czech Republic & High & Luxembourg & High \\
\hline Denmark & Low & Malta & High \\
\hline Estonia & Medium & Netherlands & Medium \\
\hline Finland & High & Poland & High \\
\hline France & High & Portugal & High \\
\hline Germany & Medium & Slovakia & High \\
\hline Greece & High & Slovenia & High \\
\hline Hungary & High & Spain & Medium \\
\hline Ireland & Medium & Sweden & Low \\
\hline Italy & High & U.K. & \\
\hline Latvia & High & &
\end{tabular}


The final parameter chosen for inclusion in the study is the existence of academic tenure. It has been argued by Chait and Ford that 'academic freedom can survive apart from tenure' (Chait and Ford, 1982, 341), while Sartorius's analysis (Sartorius, 1975) concluded that tenure is not a necessary or sufficient condition for the protection of the faculty given that, in the United States at least, a large proportion of academics do not have tenure. However, the UNESCO recommendations, which were designed to be internationally applicable, unequivocally state: 'Tenure ... constitutes one of the major procedural safeguards of academic freedom' (UNESCO, 1997, 32), a view endorsed by McPherson and Schapiro who note that 'Faculty members with tenure will have more independence. Administrators need to rely more on persuasion and less on negative sanctions ... Tenure increases the ability of faculty collectively to shape institutional decisions, through their actions in departments, colleges, or the institution as a whole' (McPherson and Schapiro, 1999, 81). More importantly, in respect to academic freedom, De George remarks that 'By giving a large number of the faculty tenure ... they are in a position to defend the academic freedom not only of themselves but of all the non-tenured members of the institution, as well as the academic freedom of faculty at other institutions' (De George, 2003, 18). In addition, as Menand points out 'Academic freedom not only protects sociology professors from the interference of trustees and public officials in the exercise of their jobs as teachers and scholars; it protects them from physics professors as well' (Menand, 1996, 17).

Unfortunately Byse and Joughin found that analysing tenure is problematic because 'Tenure is embodied in a bewildering variety of policies, plans and practices; the range reveals extraordinary differences in generosity, explicitness and intelligibility. ... there is no consensus concerning either the criteria or the procedures for acquiring and terminating tenure' (Byse and Joughin, 1959, 133). However, in those E.U. states where staff are granted tenure (albeit after a probationary term), and which can only be terminated for just cause (usually relating to repeated incompetence, dishonesty and, in some states, financial exigency), tenure is, in Van Alstyne's words, 'translatable as a statement of formal assurance that the individual's professional security and academic freedom will not be placed in question without the observance of full academic due process' (Van Alstyne, 1971, 329). In such circumstances, the protection provided for academic freedom will be high while, by contrast, in states in which there is no tenure whatsoever for staff, the protection for academic freedom will be low. 
As with many other parameters of academic freedom, between these two opposite poles there will be a variety of tenure procedures offering varying degrees of protection. Moreover, in some European states, national employment legislation on dismissal may make a law on academic tenure unnecessary. In some European nations, for example France and Portugal, academic staff have the same employment status, rights and protections as civil servants and, thereby, the same level of job security. In other nations, the process of recruitment to tenured posts is undergoing change. For example, in Spain the Conservative Government introduced reforms to the process of university staff selection in 2002, but when the Socialists were returned to power in 2004, the system was frozen and another process is being introduced. As with the other parameters considered in this study, the procedures for granting tenure were scrutinised and allocated the descriptions of high, medium or low, in accordance with the level of job security offered to staff - examples of how this was undertaken are given in table 9 below.

Table 9 Legislation to protect academic tenure - examples

\begin{tabular}{|l|l|}
\hline \multicolumn{1}{|c|}{$\begin{array}{c}\text { State/Level of } \\
\text { Protection }\end{array}$} & \multicolumn{1}{c|}{ Legislation to protect academic tenure } \\
\hline \multirow{4}{*}{$\begin{array}{l}\text { Austria } \\
\text { Medium }\end{array}$} & $\begin{array}{l}\text { Act No. 120/2002 / 9th August, 2002. Chapter 3, University academic and art staff - University } \\
\text { Professors } \\
\text { 97. The professors shall be responsible for research and teaching, or the advancement and } \\
\text { appreciation of the arts, and for teaching in their field, and shall be employed by the university } \\
\text { on a temporary or permanent basis. They shall be full-or part-time employees. } \\
\text { (3) University professors shall be appointed by the rector following an appointment procedure } \\
\text { in accordance with sections 98 or 99. } \\
\text { Term of employment contracts: 109. (1) Employment contracts may be of indefinite or } \\
\text { limited term. The term of limited term employment contracts shall not exceed six years, on } \\
\text { pain of invalidity, unless otherwise provided for by this Act }\end{array}$ \\
\hline $\begin{array}{l}\text { Greece } \\
\text { High }\end{array}$ & $\begin{array}{l}\text { Greek Constitution 11 June 1975 Article 17: 6. Professors of university level institutions shall } \\
\text { be public functionaries. The remaining teaching personnel likewise perform a public } \\
\text { function, under the conditions specified by law. Professors of university level institutions } \\
\text { shall not be dismissed prior to the lawful termination of their term of service, except in the } \\
\text { cases of the substantive conditions provided by article 88 paragraph 4 and following a } \\
\text { decision by a council constituted in its majority of highest judicial functionaries, as specified } \\
\text { by law. Law 2083 in 1992 Only those belonging to the two upper ranks of the academic } \\
\text { hierarchy are elected to permanent (tenured) positions. Appointments and promotion of all } \\
\text { teaching staff is made by special electoral bodies, which meet together with the General } \\
\text { Assemblies of the departments }\end{array}$ \\
\hline $\begin{array}{l}\text { Education Act 16th April, 1991, Part V Section 33. The Council shall be the supreme } \\
\text { governing body of the University and shall have the following functions: } \\
\text { (b) to establish and abolish posts of an academic nature or otherwise; } \\
\text { (e) to make appointments to posts, of an academic nature or otherwise, in accordance with } \\
\text { procedures established by statutes }\end{array}$ \\
\hline
\end{tabular}

This data revealed that it is rare for academics to be offered tenure unconditionally, and even where tenure is offered, it is usually following a probationary period. Hence, in many countries academic posts are filled by a competitive process, and employment is offered for limited periods. In the case of Lithuania, for example, Professors have to compete for 
employment for a five year period, but if they win a competition for a third five year period, they acquire the right to hold the post until they are 65. In the Netherlands there is no law protecting academic tenure, and although Professors had, de facto, tenure owing to their employment status as civil servants, this situation is changing as greater institutional autonomy brings with it a shift towards institutional and individual contracts for academic staff. Similarly, in the U.K., there is no law protecting tenure, in fact legislation was enacted specifically to remove tenure from University staff. Applying the descriptions of High, medium and low to the legislation relating to tenure in all the sample nations, gives the results in table 10, which shows that the system for granting tenure offers high protection for academic freedom in eleven states, and medium protection in nine, while in the U.K. only academic staff in the "old” university sector, and who were appointed before November 1987, have any employment protection.

Table 10 Legislation to protect academic tenure - summary

\begin{tabular}{|c|c|c|c|}
\hline Nation & Level of Protection & Nation & Level of Protection \\
\hline Austria & Medium & Lithuania & Medium \\
\hline Czech Republic & High & Luxembourg & Medium \\
\hline Denmark & Low & Malta & Low \\
\hline Estonia & Medium & Netherlands & Medium \\
\hline Finland & High & Poland & High \\
\hline France & High & Portugal & High \\
\hline Germany & Medium & Slovakia & Medium \\
\hline Greece & High & Slovenia & High \\
\hline Hungary & High & Spain & High \\
\hline Ireland & High & Sweden & Low \\
\hline Italy & Medium & U.K. & \\
\hline Latvia & Medium & & \\
\hline
\end{tabular}

\section{Summary and Conclusions}

Combining the results of the previous tables enables the summary Table 11 to be derived. The data demonstrates that there is a high level of consensus in many of the descriptions of academic freedom and the methods for protecting it, although there are differences between the level of protection offered in different states. The table shows that, despite the subjectivity involved in applying descriptors to the different legal measures, there is general consistency within countries between the descriptions of the parameters of the health of academic freedom that were used. As can be seen, in five countries the level of protection for academic freedom is high across all five parameters, and three of the states in this group were formerly under the influence of the USSR. By contrast, in terms of the health of academic freedom, the U.K. is clearly the sick man of Europe. In Finland (for example), freedom of speech and academic freedom are protected by the constitution, and in legislation, the system of governance 
ensures that the academic staff have a majority voice in institutional decision making, the Rector is an elected, internal appointment, and academic tenure is protected, and academic staff have the status of civil servants. By contrast, in the U.K., there is no constitutional protection for either freedom of speech or academic freedom, the law on academic freedom is designed to ensure 'just cause' for employment termination, the academic staff have only a minor input in the decision making process, the Rector is an external appointment over which they have no rights, and academic tenure exists for only a few staff, who are dwindling in number as retirement beckons. These circumstances have led Barnett to argue that 'In such an environment academic freedom is not taken away; rather, the opportunities for its realisation are reduced' (Barnett, 1997, 53).

Table 11 Summary table of results.

\begin{tabular}{|c|c|c|c|c|c|}
\hline Nation & $\begin{array}{c}\text { Constitutional } \\
\text { Protection }\end{array}$ & $\begin{array}{c}\text { Specific } \\
\text { Legislative } \\
\text { Protection }\end{array}$ & $\begin{array}{c}\text { Self } \\
\text { Governance }\end{array}$ & $\begin{array}{c}\text { Appointment of } \\
\text { Rector }\end{array}$ & Academic Tenure \\
\hline Finland & High & High & High & High & High \\
\hline Slovenia & High & High & High & High & High \\
\hline Czech Republic & High & High & High & High & High \\
\hline Hungary & High & High & High & High & High \\
\hline Spain & High & High & High & High & High \\
\hline Latvia & High & High & High & High & Medium \\
\hline Lithuania & High & High & High & High & Medium \\
\hline Slovakia & High & High & High & High & Medium \\
\hline Poland & High & Medium & High & High & High \\
\hline Austria & High & Medium & High & High & Medium \\
\hline France & Medium & High & Medium & High & High \\
\hline Portugal & High & Medium & Medium & High & High \\
\hline Italy & High & Low & High & High & Medium \\
\hline Greece & Medium & Low & Medium & High & High \\
\hline Estonia & High & Medium & High & Medium & Medium \\
\hline Germany & Medium & High & High & Medium & Medium \\
\hline Ireland & Medium & High & Low & Medium & High \\
\hline Luxembourg & Medium & Medium & Medium & High & Medium \\
\hline Malta & Medium & Low & Medium & High & Low \\
\hline Sweden & Medium & Low & Low & Medium & High \\
\hline Denmark & Medium & Medium & Low & Low & Low \\
\hline Netherlands & Low & Low & Low & Medium & Medium \\
\hline U.K. & Low & Low & Low & Low & Low \\
\hline
\end{tabular}

In 1963, Lord Chorley, the General Secretary of the U.K. Association of University Teachers, declaimed: 'On balance I think it is fair to say that academic freedom is enjoyed as fully in English universities as anywhere else in the world. ... British academic staff have very little to complain of' (Chorley, 1963, 650, 666). Such a comment would not be made today, despite the belief expressed in 1994 by the U.K. minister for further and higher education that 'The tradition of "academic freedom" is accepted by all interests, and is jealously guarded' (Boswell, 1994). Indeed, the eradication of academic freedom in the U.K. has led Kogan (who 
had previously been the Vice-Chancellor of a U.K. University) to comment 'it is not easy to see what can be recommended to the attention of colleagues in other countries' and to hope that universities in Portugal (and, one suspects, elsewhere in the E.U.) 'will not be made to follow the British example' (Kogan, 2001, 56f).

Universities in many E.U. states are experiencing pressure to move towards the British model of greater managerialism, which has been accompanied by the decline in academic freedom in the U.K. The reasons for this shift are complex, but include the (apparent) need for greater managerial professionalism, both as the participation rate in higher education rises, and as the universities' research role becomes ever more important in determining national prosperity, within the emerging global knowledge economy. However, OECD statistics reveal that the participation rate in higher education in 2003 was $73 \%$ in Finland, but only $48 \%$ in the U.K. (OECD, 2005, table C2.2). Similarly, irrespective as to the method utilised to measure the growth of the national knowledge economy, or the university sector's contribution to it, OECD statistics show that Finland consistently outscores the U.K., and most other E.U. states (OECD, 2003). This suggests that increased managerialism (and the accompanying reduction in academic freedom) does not aid achievement of the new goals assigned to higher education, indeed the opposite may be the case. Moreover, given the convergence between universities and other knowledge based companies, it is worth noting that 'the hierarchical model of management that has gained such prominence in higher education in recent years has actually won few supporters in the modern business world. ... the principles and practices of shared governance that have emerged over the past century in our best colleges and universities have more relevance for businesses in the new economy than a highly questionable model of corporate governance has for our institutions of higher education’ (Gerber, 2001, 25). Furthermore, attempts to introduce greater managerial control in higher education may prove counterproductive for, as Birnbaum, in his study of management fads in higher education, points out, 'it is no easier to get people to implement a management strategy inconsistent with their values than it is to get internal combustion from water' (Birnbaum, 2001, xii).

This study demonstrates the possibility of providing comparable measures of the legal protection for academic freedom in Europe, reveals that the health of academic freedom varies between states and needs nurturing if it is to survive, and suggests how this preliminary comparative analysis could usefully be carried forward. First, this analysis should be extended to include academic staff both in Bulgaria and Romania, (which entered the E.U. while this research was being conducted) and in the other institutions of European higher education, 
notably the polytechnics and the private sector universities. Secondly, legal documents provide the quantitative "bare bones" of academic freedom, but what is also required is a qualitative analysis of how these legal documents are interpreted within the everyday interactions of academic staff (Lecturers, Professors, Departmental Heads, Deans and Rectors) in European higher education. Bennich-Björkman's study of academic freedom in Sweden, in which academics were interviewed about 'their view of the content of academic freedom, on the current prospects for its survival, on the effect of institutional structures on the content of research and on the research process as such’ (Bennich-Björkman, 2004, 7), provides a useful example of how this could be successfully undertaken. Thirdly, some parallel assessment of the level of academic freedom enjoyed by students in the E.U. should be attempted. Such additional research would provide hope of realising Altbach's aspiration that 'With more data, it would be possible to create a "world academic freedom barometer" as is done for human rights, corruption, and other issues' (Altbach, 2001, 210).

Additionally, the proposed Constitution for the European Union states that 'The arts and scientific research shall be free of constraint. Academic freedom shall be respected' (E.U., 2005, 50). The Constitution received insufficient support among the E.U. nations to be enacted into law. However, if the process of integration among the 27 (and more) member states is to proceed, a document of similar status is likely to be ratified within the next decade. Further work is therefore required to ensure that such a document acknowledges and protects academic freedom. For this to be possible, first, a succinct yet inclusive and coherent working definition of academic freedom is needed for Universities in the E.U. nations, derived from, and built on, their historic commitment to this principle. Second, and more importantly, the reasons justifying academic freedom need to be voiced clearly and loudly for, as John Stuart Mill accurately and eloquently observed, '(When) the most active and inquiring intellects find it advisable to keep the general principles and grounds of their convictions within their own breasts ... the price paid for this sort of intellectual pacification is the sacrifice of the entire moral courage of the human mind' (Mill, 1951, 31). 


\section{Bibliography}

Altbach, P. (2001) ‘Academic Freedom: International Challenges and Realities', Higher Education 41: 205-219.

Anderson, D. AND Johnson, R. (1988) University Autonomy in Twenty Countries, Higher Education Division Evaluations and Investigations Program, Canberra: Australian Government Publishing $\quad$ Service, Available at www.dest.gov.au/archive/highered?eippubs/eip98-3/eip98-3.pdf>

Association of AMERICAN UnIVERSITy Professors, (1944) On the Relationship of Faculty Governance to Academic Freedom, Statement adopted by the Association's Council, June 1994.

Åkerlind, G. KaYroOz, C. (2003) 'Understanding Academic Freedom: The Views of Social Scientists', Higher Research and Development, 22(3): 327-344.

BARnetT, R. (1997) Higher Education: A Critical Business Buckingham: SRHE/Open University Press.

BenNich-BJöRKMAn, L. (2004) Has Academic Freedom Survived? Stockholm: National Agency for Higher Education.

Berdahl, R. (1990) 'Academic Freedom, Autonomy And Accountability In British Universities', Studies in Higher Education 15(2): 69-80.

BirnBAum R. (2001) Management Fads in Higher Education, San Francisco: Jossey Bass Publishers.

Boswell, T. (1994) 'Lecture on British Universities $15^{\text {th }}$ September 1994', London: Department of Education, (1994) as reported in PRITCHARD, R. 'Academic freedom and Autonomy in the United Kingdom and Germany’, Minerva 36 (1998): p.101.

BriCALL, J. (2003) 'University Institutional Autonomy’ in Case Studies: Academic Freedom and University Institutional Responsibility in Portugal, Bologna: Bononia University Press, pp. 59-71.

Byse, C. And Joughin, L. (1959) Tenure in American Higher Education: Plans, Practices and the Law, Ithaca: Cornell University Press.

ChAit, R. and Ford, A. (1982) Beyond Traditional Tenure: A Guide to Sound Policies and Practice, San Francisco: Jossey-Bass Publishers.

ChORley, R. (1963) 'Academic Freedom in the United Kingdom', Law and Contemporary Problems, 28(3): 647-671. 
Connolly, J. (2000) ‘The Academy's Freedom, The Academy's Burden’, Thought and Action 16(1): 69-82.

CourT, S. (1998) 'Academic Tenure And Employment In The UK’, Sociological Perspectives 41(4): 767-774.

Daughtrey, W. (1990) 'The Legal Nature Of Academic Freedom In United States Colleges And Universities', University Of Richmond Law Review 25: 233-271.

De George, R. 'Ethics, Academic Freedom and Academic Tenure', Journal of Academic Ethics 1 (2003): 11-25.

DodDs, H. (1963) 'Academic Freedom And The Academic President', Law and Contemporary Problems 28(3): 602-606.

EUROPEAN Union, (2000) 'Charter of Fundamental Rights of the European Union', Official Journal of the European Communities, $18^{\text {th }}$ December.2000: 364/1-21.

European Union. (2005) Constitution Of The European Union Luxembourg: Office for Official Publications of the European Communities, 2005.

EUROPEAn Universities Association. (1988) Magna Charta Universitatum.

European Universities Association. (2001) Shaping the European Higher Education Area (The Salamanca Declaration) 2001.

Gerber, L. (2001). “'Inextricably Linked”: Shared Governance and Academic Freedom’, Academe 87(3): 22-24.

House of Commons. Debate 1st December 1987, Vol. 123, cc771-81.

Kogan, M. (2003) 'The Mission of the University' in Case Studies: Academic Freedom and University Institutional Responsibility in Portugal, Bologna: Bononia University Press pp. 47-57.

KWIEK, M. (2003) 'Academe in transition: Transformations in the Polish academic profession', Higher Education, 45(4): 455-476.

LAY, P. (2004) The Interpretation of the Magna Charta Universitatum and its Principles, Bologna: Bononia University Press.

LiEBERWITZ, R. 'The Corporatisation of the University: Distance Learning at the Cost of Academic Freedom?’ Boston University Public Interest Law Journal, 12: 73-135.

McMaster, M. (2002) 'Partnerships between Administrative and Academic Managers: How Deans and Faculty Managers Work Together', ATEM-AAPPA Conference, Brisbane.

McPherson, M. and Schapiro, M. (1999) 'Tenure Issues in Higher Education”, in Devlin. M.E. Montgomery, J.W. (eds), Forum Strategy Series, Forum Futures 1999 Papers, Washington: Forum Publishing, pp. 73-88. 
MenAnd, L. (1996)'The Limits of Academic Freedom’, in The Future of Academic Freedom, (ed.) Menand, L (ed), Chicago: University of Chicago Press, pp. 3-20.

MiLl, J. S. (1951) Utilitarianism, Liberty and Representative Government, London: Everymans.

NYBORG, P. (2003) 'Institutional autonomy and higher education governance', Council of Europe Conference: Implications of the Bologna Process in South East Europe, Strasbourg, 2-3 December.

OECD, (2005) Education at a Glance 2005, Paris: OECD.

OECD, (2003) Science, Technology and Industry Scoreboard 2003, Paris: OECD.

PRITCHARD, R. (1998) 'Academic freedom and Autonomy in the United Kingdom and Germany’, Minerva 36(2): 101-124.

RochFORD, F. (2003) 'Academic freedom as insubordination: the legalisation of the academy', Education and the Law, 15(4): 249-262.

Rothblatt, S. (1999) 'Academic freedom and institutional autonomy in historical perspective', Conference Proceedings, Association of Swedish Higher Education, Conference on Akademisk Frihet, Karlstad University, 2nd November, 1999) 17-30.

RAELIN, J. (2003) ‘Should Faculty be “Managed”?’, Academe, 89(3): 40-44.

SARTORIUS, R. (1975) 'Tenure and Academic Freedom', in The Concept of Academic Freedom, (ed.) Pincoffs, E. Austin: University of Texas Press, pp. 133-158.

ScotT, J. Chair of the AAUP's Committee on Academic Freedom and Tenure, quoted by Bowen, R. in 'For The Record: Born Free but in Chains: Academic Freedom and Rights of Governance', Academe, 912 (March-April, 2005): 119-122.

SMITH, N. 'Constitutional Academic Freedom', South African Law Journal, 112 (1995): 678690.

STANDLER, P. Academic Freedom in the USA 2000. < Available at http://rbs2.com/afree.htm>

Stuller, W. 'High School Academic Freedom: The Evolution of a Fish Out of Water', Nebraska Law Review, 77, (1998): 301-343.

ThOREns, J. 'Liberties, Freedom and Autonomy: A Few Reflections on Academia's Estate', Higher Education Policy 19 (2006): 87-110.

TIERNEY, W. 'Academic Freedom and Organisational Identity', Australian Universities Review, 441 (2001): 7-14.

Turner, J. 'The Price of Freedom', in Academic Freedom and Responsibility, (ed) Tight, M. Buckingham: SRHE/OU Press 1988: 104-113. 
UNESCO, Records of the General Conference, Twenty-ninth Session Paris, 21 October to 12 November 1997, Volume 1 Resolutions: 26-36.

Van Alstyne, W. 'Tenure: A Summary, Explanation, and Defense', Association of American University Professors Bulletin, 57 (Autumn 1971): 329-351.

White, L. 'Academic Tenure: Its Historical And Legal Meanings In The United States And Its Relationship To The Compensation Of Medical School Faculty Members', Saint Louis University Law Journal 44 (2000): 51-80. 